\title{
Stavovi studenata studija sestrinstva Zdravstvenog veleučilišta o sestrinstvu u Hrvatskoj
}

1 Mateo Kosier

2 Snježana Čukljek

2 Damir Lučanin

1 Klinički bolnički centar Sestre milosrdnice

2 Zdravstveno veleučilište Zagreb

\section{Sažetak}

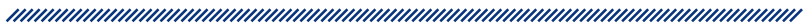

Sestrinstvo je danas priznata profesija koju nitko ne osporava. Moderno sestrinstvo favorizira edukaciju kao prioritet u profesionalnom životu medicinskih sestara. Više i visoko obrazovanje medicinskih sestara standard je u modernim državama. Uspješnost medicinske sestre ne ovisi samo o njezinoj humanosti i sposobnosti svladavanja suvremene tehnologije nego i o trajnoj edukaciji medicinskih sestara. Cilj ovoga istraživanja bio je istražiti kakvi su stavovi i mišljenja studenata svih godina preddiplomskog studija sestrinstva o sestrinstvu, identitetu profesije, ulozi i položaju u zdravstvenom timu i obrazovanju, odnosno promjenama i mogućnostima u obrazovanju medicinskih sestara i tehničara u Republici Hrvatskoj. U istraživanju je sudjelovao ukupno 281 sudionik sa svih godina preddiplomskog studija sestrinstva. Najveći broj ispitanih, njih 87,19\% (N=245) u dobi je od 19 do 22 godine, prema očekivanju, veći je broj ispitanih osoba ženskog spola, njih 91,46\% ( $=257)$, dok je u istraživanju sudjelovalo samo $8,54 \%(\mathrm{~N}=24)$ ispitanika muškog spola. Dobiveni rezultati upućuju na veliku zainteresiranost za jačanje sestrinstva kao profesije te napredak sestrinstva k svjetlijoj i boljoj budućnosti u Republici Hrvatskoj.
Ključne riječi: sestrinstvo, edukacija, istraživanje, profesionalnost, stavovi

Datum primitka: 01.10.2018.

Datum prihvaćanja: 20.10.2018.

DOI: $10.24141 / 1 / 4 / 2 / 1$

Adresa za dopisivanje: Mateo Kosier, bacc. med. techn. tel.: +385981372477 e-pošta: mateo.kosier@gmail.com 


\section{Uvod}

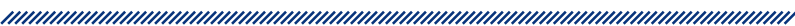

Zdravstvena njega, a time i sestrinska profesija, postupno se razvijala od pomagačke do samostalne djelatnosti. Usporedo s razvojem medicinskih znanosti razvija se sestrinska znanost, a povećanjem djelokruga rada i povisivanjem razina sestrinskog obrazovanja, primjenom većeg broja samostalnih sestrinskih intervencija te razvojem sestrinskih istraživanja dolazi do profesionalizacije sestrinstva u Hrvatskoj. Potrebe za dobro i visokoobrazovanim medicinskim sestrama u sustavu zdravstva rastu s razvojem medicinskih i sestrinskih znanosti, primjenom sve složenijih oblika liječenja, sve većim zdravstvenim potrebama pacijenata, primjenom novih dijagnostičkih postupaka, uvođenjem procesa zdravstvene njege te sestrinske dokumentacije. Obrazovanju medicinskih sestra pridaje se sve veća pozornost, a cilj je obrazovanja pripremiti studenta za odgovorno i profesionalno obavljanje poslova medicinske sestre i ostanak u profesiji te utjecati na razvoj pozitivnih stavova prema sestrinstvu.

Obrazovanje medicinskih sestara u Republici Hrvatskoj organizirano je na srednjoškolskoj i visokoškolskoj razini. Srednjoškolsko obrazovanje traje pet godina, a nakon završenog obrazovanja učenici stječu zvanje „medicinska sestra / medicinski tehničar opće zdravstvene njege". Preddiplomski studij sestrinstva traje tri godine, student završetkom studija stječe naziv „prvostupnik/ prvostupnica sestrinstva”, a završetkom diplomskog studija koji traje još dvije godine „diplomirana medicinska sestara / medicinski tehničar” odnosno „magistar/ magistra sestrinstva”. Obrazovanje medicinskih sestra u zemljama Europe, tako i Hrvatskoj mora biti usklađeno s odrednicama direktiva Direktive 2005/36/EC i Direktive 2013/55/EU koje definiraju minimalne standarde glede sadržaja i trajanja studija ${ }^{1,2}$.

Studenti upisuju studij sestrinstva iz želje da pomognu drugima $^{3,4}$ no i zbog sigurnosti radnog mjesta ${ }^{3,4,5}$.

$\mathrm{Na}$ percepciju sestrinske profesije znatan utjecaj ima prikaz medicinskih sestara u javnosti, pri čemu važnu ulogu imaju mediji i društvene mreže. Medicinske sestre često se u medijima prikazuju kao stereotipni prikazi ili kroz probleme profesije. Uz sestrinstvo se vezuje niz stereotipija. Pritom pojedine stereotipije imaju povijesna polazišta, kao što je medicinska sestra anđeo, a feminizirani prikaz profesije vezuje se uz Florence Nightingale. Kao vodeće stereotipije prikazuju se medicinska sestra anđeo, oštrokondža, nestašna (seksi) sestra i pomoćnica liječnika ${ }^{6,7,8}$. Kao najčešći prikazi na kanalu YouTube izdvajaju se medicinska sestra kao „vješti znalac i činilac”, nestašna (seksi) sestra i nekompetentna osoba ${ }^{8}$.

Vrlo se često medicinske sestre prikazuju kroz probleme profesije: nedostatak radne snage, veliku opterećenost poslom te probleme na radnom mjestu ${ }^{9}$. $U$ istraživanju provedenom u Sjedinjenim Američkim Državama medicinske sestre smatraju da najveći utjecaj na percepciju sestrinstva u javnosti ima način kako se medicinske sestre prezentiraju pacijentima i obiteljima, koliko su vješte u svojem poslu te smatraju li pacijenti i obitelji da se sestre brinu. Medicinske sestre navode da mogu poboljšati svoju sliku u javnosti profesionalnom odjećom i ponašanjem, promjenom svijesti zajednice te iskazivanjem suosjećanja ${ }^{10}$.

Javnost različito percipira medicinske sestre. $U$ istraživanju provedenom u Sjedinjenim Američkim Državama ispitanici navode da je sestrinstvo vrlo cijenjena profesija i većina bi osoba preporučila sestrinstvo kao profesionalnu karijeru. Sestrinstvo doživljavaju kao kombinaciju njegovanja i znanja, vještina i profesionalizma ${ }^{11}$. Suprotne rezultate navode ten Hoeve i suradnici - rezultati njihova istraživanja govore da društvo još uvijek medicinske sestre vidi kao podređene liječnicima, kao one kojima nije potrebno akademsko obrazovanje i nemaju profesionalnu autonomiju ${ }^{12}$.

Znatan problem u obrazovanju medicinskih sestra predstavlja odustaje studenata od studija. Istraživanja navode da u Australiji i Kanadi na pojedinim visokim učilištima čak do $40 \%$ upisanih studenata odustaje od studija, u Nizozemskoj od $20 \%$ do čak $50 \%$ studenata $^{13}$, a u Italiji 19 do $20 \%$ studenata $^{14}$. Kao razlozi odustajanja od studija navode se osobni razlozi i obiteljske obveze, zahtjevnost edukacijskog programa te nepoznavanje sestrinske profesije ${ }^{13,14}$. S obzirom na to da veliki dio studenata sestrinstva u Hrvatskoj prethodno završava srednju školu za medicinske sestre opće njege, odustajanje od studija nije toliko velik problem, manji dio studenata odustaje od studija uglavnom iz obiteljskih i osobnih razloga. Ipak poneki student u generaciji diplomanada navodi da ne planira raditi u sestrinstvu nakon završetka studija.

Podrška studentima i učenje u kliničkoj okolini važni su čimbenici koji utječu na usvajanje profesionalnih vrijednosti, završetak studija te rad u profesiji. Upravo kao najvažniji čimbenici koji pridonose profesionalizaciji izdvajaju se edukacija ${ }^{15-19}$ te usvajanje teorijskih i praktičnih znanja ${ }^{20}$. 
Na početku studija studenti posjeduju stavove i uvjerenja o sestrinstvu koji se mijenjaju pod utjecajem obrazovnog programa $^{21-25}$. Kod studenata se tijekom studija smanjuje idealistična slika sestrinstva u odnosu na početak studija, a usvaja se profesionalna slika o sebi, vještine, fleksibilnost, zadovoljstvo, znanje i profesionalne vrijednosti ${ }^{19,21}$, te dolazi do razvoja profesionalnog identiteta.

$\mathrm{Na}$ kraju studija studenti imaju izraženiji stav da su intervencije koje pružaju medicinske sestre jednako važne kao i intervencije koje pružaju liječnici, da su istraživanja nužna za razvoj sestrinstva ${ }^{26,27}$ te da medicinske sestre nisu adekvatno plaćene za svoj rad ${ }^{3,26}$. lako smatraju da je sestrinstvo malo plaćeno zanimanje, većina ispitanika navodi da su ponosni što će postati medicinske sestre / medicinski tehničari ${ }^{3}$ te planiraju raditi u profesiji.

Do sada je u Hrvatskoj proveden mali broj istraživanja na studentima sestrinstva u svrhu utvrđivanja stavova studenata sestrinstva prema sestrinstvu, stoga je svrha ovog rada provesti neke aspekte validacije upitnika adaptiranog za primjenu u ovom istraživanju te provjeriti kakvi su stavovi i mišljenja studenata svih godina preddiplomskog studija sestrinstva. Zanimalo nas je mišljenje budućih profesionalaca, medicinskih sestara i tehničara, o sestrinstvu, identitetu profesije, ulozi i položaju u zdravstvenom timu, kao i stavove o obrazovanju, odnosno mišljenja o promjenama i novim mogućnostima u obrazovanju medicinskih sestara i tehničara u Republici Hrvatskoj.

\section{Metode}

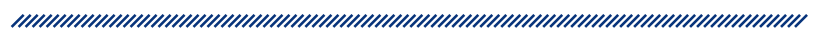

\section{Ispitanici}

Ispitanici koji su ispunjavanjem upitnika, sudjelovali u ovom istraživanju studenti su prve, druge i treće godine preddiplomskog studija sestrinstva Zdravstvenog veleučilišta. U istraživanju je sudjelovao 281 student (257 studentica i 24 studenta), odnosno po godinama studija broj sudionika bio je: 88 studenata prve godine studija, 89 studenata druge godine studija te 104 studenta treće godine.

\section{Anketni upitnik}

Za ovo istraživanje primijenjena je anonimna anketa koja se sastojala od dva dijela. Prvi je dio sadržavao tri otvorena pitanja koja su se odnosila na dob, spol i godinu studija sudionika, dok su pitanja drugog dijela bila strukturirana, odnosno zatvorenog tipa. Pitanja zatvorenog tipa ispitivala su stavove uz primjenu Likertove ljestvice. Ova pitanja sadržajem su se odnosila na sestrinstvo, identitet profesije, obrazovanje medicinskih sestara i položaj u zdravstvenom sustavu.

Primijenjena Likertova ljestvica oblikovana je tako da se pokuša doznati stupanj slaganja odnosno neslaganja sudionika s nekom tvrdnjom, tj. njegov stav prema nekoj tvrdnji. Ovaj tip pitanja/ljestvica se uobičajeno primjenjuje u anketnim istraživanjima. Kod svih pitanja zatvorenog tipa primijenjena je ljestvica od pet stupnjeva koji su označavali stupanj slaganja s tvrdnjom: 1 uopće se ne slažem, 2 - uglavnom se ne slažem, 3 - niti se slažem niti se ne slažem, 4 - uglavnom se slažem i 5 - u potpunosti se slažem.

\section{Postupak}

Sudionici su anketu najčešće ispunjavali u obliku papir-olovka, a manji dio putem interneta. Ispunjavanje ankete uvijek je bilo anonimno. Ispitanicima je objašnjeno da je upitnik anoniman te da je istraživanje dio završnog rada studenta završne godine studija sestrinstva na Zdravstvenom veleučilištu Zagreb. Anketiranje je provedeno od veljače do travnja 2016. godine. Etičko povjerenstvo Zdravstvenog veleučilišta odobrilo je istraživanje.

\section{Rezultati}

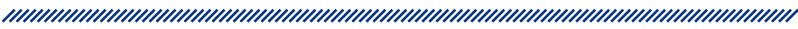

Dob sudionika kretala se u rasponu od 19 do 32 godine, a prosječna dob je bila 21,19 godina uz standardnu devijaciju 1,96 .

\begin{tabular}{|c|c|c|c|}
\hline \multicolumn{4}{|c|}{ Tablica 1. Spol ispitanika } \\
\hline SPOL & 1. GODINA & 2. GODINA & 3. GODINA \\
\hline MUŠKI & $10,2 \%$ & $11,2 \%$ & $4,8 \%$ \\
\hline ŽENSKI & $89,8 \%$ & $88,8 \%$ & $95,2 \%$ \\
\hline Ukupno & $100 \%$ & $100 \%$ & $100 \%$ \\
\hline
\end{tabular}




\section{Tablica 2. Rezultati odgovora na tvrdnje - postotak izabranih odgovora na pojedino pitanje u} svakoj godini studija

\section{PITANJE}

1. Obrazovanje medicinskih sestara u Republici Hrvatskoj adekvatno je organizirano i osigurava potrebna znanja i vještine.

2. Medicinske sestre raspolažu s dovoljno znanja i vještina za samostalan rad.

3. Medicinska sestra može napredovati i steći znanja u području osobnog i profesionalnog interesa.

4. Drugi članovi tima cijene medicinske sestre.

5. Medicinske su sestre primjereno plaćene za posao koji obavljaju.

6. Sestrinstvo je cijenjena profesija u Republici Hrvatskoj.

7. Cjeloživotno je usavršavanje važno u sestrinskoj profesiji.

8. Istraživanje u sestrinstvu važno je u unaprjeđivanju struke, ali i funkcioniranju cjelokupnoga zdravstvenog sustava.

9. Prikaz rada medicinskih sestara i ostalih zdravstvenih profesionalaca u medijima je adekvatan.

\begin{tabular}{|c|c|c|c|}
\hline & $1 . G O D I N A$ & $2 . G O D I N A$ & 3. GODINA \\
\hline 1 & $4,55 \%$ & $5,62 \%$ & $8,65 \%$ \\
\hline 2 & $13,64 \%$ & $15,73 \%$ & $28,85 \%$ \\
\hline 3 & $29,55 \%$ & $30,34 \%$ & $31,73 \%$ \\
\hline 4 & $45,45 \%$ & $40,45 \%$ & $27,88 \%$ \\
\hline 5 & $6,82 \%$ & $7,87 \%$ & $2,88 \%$ \\
\hline 1 & $0,00 \%$ & $2,25 \%$ & $1,92 \%$ \\
\hline 2 & $0,00 \%$ & $7,87 \%$ & $14,42 \%$ \\
\hline 3 & $18,18 \%$ & $25,84 \%$ & $25,00 \%$ \\
\hline 4 & $60,23 \%$ & $41,57 \%$ & $50,00 \%$ \\
\hline 5 & $21,59 \%$ & $22,47 \%$ & $8,65 \%$ \\
\hline 1 & $1,14 \%$ & $2,25 \%$ & $1,92 \%$ \\
\hline 2 & $3,41 \%$ & $13,48 \%$ & $3,85 \%$ \\
\hline 3 & $14,77 \%$ & $10,11 \%$ & $31,73 \%$ \\
\hline 4 & $29,55 \%$ & $48,31 \%$ & $40,38 \%$ \\
\hline 5 & $51,14 \%$ & $25,84 \%$ & $22,12 \%$ \\
\hline 1 & $4,55 \%$ & $7,87 \%$ & $8,65 \%$ \\
\hline 2 & $29,55 \%$ & $31,46 \%$ & $39,42 \%$ \\
\hline 3 & $47,73 \%$ & $47,19 \%$ & $34,62 \%$ \\
\hline 4 & $17,05 \%$ & $12,36 \%$ & $15,38 \%$ \\
\hline 5 & $1,14 \%$ & $1,12 \%$ & $1,92 \%$ \\
\hline 1 & $39,77 \%$ & $41,57 \%$ & $37,50 \%$ \\
\hline 2 & $37,50 \%$ & $43,82 \%$ & $45,19 \%$ \\
\hline 3 & $19,32 \%$ & $6,74 \%$ & $11,54 \%$ \\
\hline 4 & $2,27 \%$ & $4,49 \%$ & $4,81 \%$ \\
\hline 5 & $1,14 \%$ & $3,37 \%$ & $0,96 \%$ \\
\hline 1 & $17,05 \%$ & $23,60 \%$ & $19,23 \%$ \\
\hline 2 & $42,05 \%$ & $40,45 \%$ & $42,31 \%$ \\
\hline 3 & $29,55 \%$ & $25,84 \%$ & $21,15 \%$ \\
\hline 4 & $6,82 \%$ & $5,62 \%$ & $14,42 \%$ \\
\hline 5 & $4,55 \%$ & $4,49 \%$ & $2,88 \%$ \\
\hline 1 & $0,00 \%$ & $1,12 \%$ & $0,00 \%$ \\
\hline 2 & $0,00 \%$ & $0,00 \%$ & $0,00 \%$ \\
\hline 3 & $0,00 \%$ & $2,25 \%$ & $0,96 \%$ \\
\hline 4 & $12,50 \%$ & $25,84 \%$ & $27,88 \%$ \\
\hline 5 & $87,50 \%$ & $70,79 \%$ & $71,15 \%$ \\
\hline 1 & $0,00 \%$ & $1,12 \%$ & $0,00 \%$ \\
\hline 2 & $1,14 \%$ & $1,12 \%$ & $0,00 \%$ \\
\hline 3 & $4,55 \%$ & $3,37 \%$ & $9,62 \%$ \\
\hline 4 & $26,14 \%$ & $41,57 \%$ & $37,50 \%$ \\
\hline 5 & $68,18 \%$ & $52,81 \%$ & $52,88 \%$ \\
\hline & $22,73 \%$ & $16,85 \%$ & $15,38 \%$ \\
\hline 3 & $12,36 \%$ & $60,67 \%$ & $45,19 \%$ \\
\hline
\end{tabular}


Tablica 2. Rezultati odgovora na tvrdnje - postotak izabranih odgovora na pojedino pitanje $u$ svakoj godini studija

\begin{tabular}{|c|c|c|c|c|}
\hline PITANJE & & 1.GODINA & 2.GODINA & 3.GODINA \\
\hline \multirow{5}{*}{$\begin{array}{l}\text { 10. Smatram da je u obraćanju članovima tima pravilno oslovljavati } \\
\text { medicinske sestre samo imenom, a liječnika titulom i prezimenom. }\end{array}$} & 1 & $65,91 \%$ & $78,65 \%$ & $74,04 \%$ \\
\hline & 2 & $17,05 \%$ & $14,61 \%$ & $15,38 \%$ \\
\hline & 3 & $13,64 \%$ & $5,62 \%$ & $9,62 \%$ \\
\hline & 4 & $3,41 \%$ & $0,00 \%$ & $0,96 \%$ \\
\hline & 5 & $0,00 \%$ & $1,12 \%$ & $0,00 \%$ \\
\hline \multirow{5}{*}{$\begin{array}{l}\text { 11. Liječničke upute i smjernice imaju apsolutno autoritativnu snagu } \\
\text { za sestrinsku profesiju samo ako su povezane s liječenjem bolesnika. }\end{array}$} & 1 & $3,41 \%$ & $10,11 \%$ & $10,58 \%$ \\
\hline & 2 & $20,45 \%$ & $15,73 \%$ & $15,38 \%$ \\
\hline & 3 & $31,82 \%$ & $41,57 \%$ & $36,54 \%$ \\
\hline & 4 & $31,82 \%$ & $21,35 \%$ & $26,92 \%$ \\
\hline & 5 & $12,50 \%$ & $11,24 \%$ & $10,58 \%$ \\
\hline \multirow{5}{*}{$\begin{array}{l}\text { 12. Medicinske su sestre autonomne u djelovanju u skladu s } \\
\text { kompetencijama vlastite profesije. }\end{array}$} & 1 & $2,27 \%$ & $4,49 \%$ & $0,00 \%$ \\
\hline & 2 & $5,68 \%$ & $13,48 \%$ & $9,62 \%$ \\
\hline & 3 & $13,64 \%$ & $42,70 \%$ & $34,62 \%$ \\
\hline & 4 & $42,05 \%$ & $24,72 \%$ & $35,58 \%$ \\
\hline & 5 & $36,36 \%$ & $14,61 \%$ & $20,19 \%$ \\
\hline \multirow{5}{*}{ 13. Medicinske su sestre pomoćnice liječnika. } & 1 & $69,32 \%$ & $49,44 \%$ & $63,46 \%$ \\
\hline & 2 & $13,64 \%$ & $26,97 \%$ & $10,58 \%$ \\
\hline & 3 & $7,95 \%$ & $11,24 \%$ & $15,38 \%$ \\
\hline & 4 & $5,68 \%$ & $8,99 \%$ & $9,62 \%$ \\
\hline & 5 & $3,41 \%$ & $3,37 \%$ & $0,96 \%$ \\
\hline \multirow{5}{*}{ 14. Napredak sestrinske struke ne ugrožava ostale članove tima. } & 1 & $1,14 \%$ & $2,25 \%$ & $1,92 \%$ \\
\hline & 2 & $0,00 \%$ & $1,12 \%$ & $2,88 \%$ \\
\hline & 3 & $5,68 \%$ & $4,49 \%$ & $8,65 \%$ \\
\hline & 4 & $18,18 \%$ & $17,98 \%$ & $26,92 \%$ \\
\hline & 5 & $75,00 \%$ & $74,16 \%$ & $59,62 \%$ \\
\hline \multirow{5}{*}{ 15. Medicinska sestra ima jednaki autoritet kao i drugi članovi tima. } & 1 & $10,23 \%$ & $25,84 \%$ & $14,42 \%$ \\
\hline & 2 & $31,82 \%$ & $29,21 \%$ & $27,88 \%$ \\
\hline & 3 & $25,00 \%$ & $26,97 \%$ & $21,15 \%$ \\
\hline & 4 & $17,05 \%$ & $10,11 \%$ & $18,27 \%$ \\
\hline & 5 & $15,91 \%$ & $7,87 \%$ & $18,27 \%$ \\
\hline \multirow{5}{*}{ 16. U budućnosti namjeravam raditi u području sestrinstva. } & 1 & $0,00 \%$ & $2,25 \%$ & $1,92 \%$ \\
\hline & 2 & $1,14 \%$ & $1,12 \%$ & $0,96 \%$ \\
\hline & 3 & $1,14 \%$ & $1,12 \%$ & $6,73 \%$ \\
\hline & 4 & $20,45 \%$ & $24,72 \%$ & $23,08 \%$ \\
\hline & 5 & $77,27 \%$ & $70,79 \%$ & $67,31 \%$ \\
\hline \multirow{5}{*}{$\begin{array}{l}\text { 17. U budućnosti namjeravam nastaviti obrazovanje te napredovati } \\
\text { na osobnom i profesionalnom planu. }\end{array}$} & 1 & $0,00 \%$ & $1,12 \%$ & $0,96 \%$ \\
\hline & 2 & $1,14 \%$ & $1,12 \%$ & $2,88 \%$ \\
\hline & 3 & $5,68 \%$ & $3,37 \%$ & $5,77 \%$ \\
\hline & 4 & $21,59 \%$ & $21,35 \%$ & $24,04 \%$ \\
\hline & 5 & $71,59 \%$ & $73,03 \%$ & $66,35 \%$ \\
\hline
\end{tabular}


Tablica 3. Deskriptivno-statistički podaci za pojedine čestice primijenjenog upitnika za procjenu stava $(\mathbf{N}=\mathbf{2 1 8})$

\begin{tabular}{|c|c|c|}
\hline Čestica & $\begin{array}{l}\text { Aritmetička } \\
\text { sredina }\end{array}$ & $\mathrm{SD}$ \\
\hline $\begin{array}{l}\text { Obrazovanje medicinskih sestara u Republici Hrvatskoj adekvatno je organizirano i osigurava } \\
\text { potrebna znanja i vještine. }\end{array}$ & 3,16 & 1,017 \\
\hline Medicinske sestre raspolažu s dovoljno znanja i vještina za samostalan rad. & 3,74 & 0,882 \\
\hline $\begin{array}{l}\text { Medicinska sestra može napredovati i steći znanja u području osobnog i profesionalnog } \\
\text { interesa. }\end{array}$ & 3,94 & 0,975 \\
\hline Drugi članovi tima cijene medicinske sestre. & 2,70 & 0,860 \\
\hline Medicinske su sestre primjereno plaćene za posao koji obavljaju. & 1,86 & 0,906 \\
\hline Sestrinstvo je cijenjena profesija u Republici Hrvatskoj. & 2,36 & 1,025 \\
\hline Cjeloživotno je usavršavanje važno u sestrinskoj profesiji. & 4,74 & 0,507 \\
\hline $\begin{array}{c}\text { Istraživanje u sestrinstvu važno je u unaprjeđivanju struke, ali i funkcioniranju cjelokupnoga } \\
\text { zdravstvenog sustava. }\end{array}$ & 4,49 & 0,677 \\
\hline $\begin{array}{l}\text { Prikaz rada medicinskih sestara i ostalih zdravstvenih profesionalaca u medijima je } \\
\text { adekvatan. }\end{array}$ & 2,15 & 0,812 \\
\hline $\begin{array}{l}\text { Smatram da je u obraćanju članovima tima pravilno oslovljavati medicinske sestre samo } \\
\text { imenom, a liječnika titulom i prezimenom. }\end{array}$ & 1,41 & 0,751 \\
\hline $\begin{array}{l}\text { Liječničke upute i smjernice imaju autoritet za sestrinsku profesiju ako su povezane s } \\
\text { liječenjem bolesnika. }\end{array}$ & 3,16 & 1,095 \\
\hline Medicinske su sestre autonomne u djelovanju u skladu s kompetencijama vlastite profesije. & 3,67 & 1,007 \\
\hline Medicinske su sestre pomoćnice liječnika. & 1,75 & 1,104 \\
\hline Napredak sestrinske struke ne ugrožava ostale članove tima. & 4,54 & 0,823 \\
\hline Medicinska sestra ima jednaki autoritet kao i drugi članovi tima. & 2,81 & 1,287 \\
\hline U budućnosti namjeravam raditi u području sestrinstva. & 4,62 & 0,733 \\
\hline $\begin{array}{c}\text { U budućnosti namjeravam nastaviti obrazovanje te napredovati na osobnom i } \\
\text { profesionalnom planu. }\end{array}$ & 4,59 & 0,731 \\
\hline
\end{tabular}

Pouzdanost je provjerena analizom svih 17 korištenih čestica oblikom interne konzistentnosti. Ova analiza upućuje na stupanj homogenosti korištenih čestica dobiveni Cronbachov alfa koeficijent 0,648 ukazuje na to da skala vjerojatno nije jednodimenzionalna. Pojedinačni koeficijenti korelacije čestica s ukupnim rezultatom prilično variraju (od 0,01 do 0,37 ). Može se uočiti da bi izbacivanjem pojedinih čestica homogenost rasla, no tada bi izostale informacije o zanimljivim dimenzijama.

Provedena je faktorska analiza postupkom glavnih komponenti uz istodobno uvođenje svih čestica, koja u nerotiranoj soluciji generira pet faktora uz $53 \%$ objašnjenja ukupne varijance.

Razlike u visini ukupnog rezultata stava o sestrinstvu, identitetu profesije, ulozi i položaju u zdravstvenom timu za različite godine studiranja provjerene jednostavnom analizom varijance pokazuju se statistički značajnima na razini rizika manjoj od $1 \% \mathrm{~F}=7,508$.

\section{Rasprava}

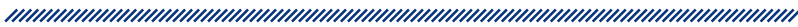

Dob ispitanika u skladu je s očekivanjima za svaku godinu studija, tako je najveći broj sudionika prve godine studija u dobi od 19 do 20 godina, ispitanici druge godine najviše su u dobi od 20 do 22 godine, dok je najviše ispitanih na trećoj godini u rasponu od 21 do 22 godine, jednako kao u istraživanju provedenom 2011. godine na trećoj godini studija sestrinstva Zdravstvenog veleučilišta u Zagrebu ${ }^{28}$.

U promatranom uzorku bilo je 5 do $10 \%$ ispitanih muškog spola, dok je udio studentica prevladavajući, što je sukladno strukturi studenata sestrinstva po spolu.

Većina ispitanih studenata prve i druge godine smatra da je obrazovanje medicinskih sestara u Republici Hr- 
Tablica 4. Rezultati faktorske analize

(po principalno komponentnom modelu uz istodobno uključivanje svih čestica bez rotacije)

Čestica

\begin{tabular}{|l|l|l|r}
\multicolumn{4}{|c}{ Faktorske komponente } \\
\hline 1 & 2 & 3 & 4 \\
\hline
\end{tabular}

Obrazovanje medicinskih sestara u Republici Hrvatskoj adekvatno je organizirano i osigurava potrebna znanja i vještine.

Medicinske sestre raspolažu s dovoljno znanja i vještina za samostalan rad.

Medicinska sestra može napredovati i steći znanja u području osobnog i profesionalnog interesa.

Drugi članovi tima cijene medicinske sestre.

\begin{tabular}{l|l}
4 & 5
\end{tabular}

0,38

\begin{tabular}{|l|l|l|l|l|}
\hline 0,386 & 0,451 & $-0,479$ & 0,148 & $-0,120$ \\
\hline 0,492 & 0,211 & $-0,494$ & 0,111 & $-0,135$ \\
\hline 0,593 & 0,226 & $-0,358$ & $-0,145$ & $-0,090$ \\
\hline 0,354 & 0,594 & 0,151 & $-0,256$ & $-0,123$ \\
\hline
\end{tabular}

Medicinske su sestre primjereno plaćene za posao koji obavljaju.

Sestrinstvo je cijenjena profesija u Republici Hrvatskoj.

0,132

0,604

0,238

$-0,051$

0,049

Cjeloživotno je usavršavanje važno u sestrinskoj profesiji.

Istraživanje u sestrinstvu važno je u unaprjeđivanju struke, ali i funkcioniranju cjelokupnoga zdravstvenog sustava.

Prikaz rada medicinskih sestara i ostalih zdravstvenih profesionalaca u medijima je adekvatan.

Smatram da je u obraćanju članovima tima pravilno oslovljavati medicinske sestre samo imenom, a liječnika titulom i prezimenom.

Liječničke upute i smjernice imaju autoritet za sestrinsku profesiju ako su povezane s liječenjem bolesnika.

Medicinske su sestre autonomne u djelovanju u skladu s kompetencijama vlastite profesije.

0,266

0,622

0,284

0,161

$-0,174$

0,586

$-0,343$

0,329

$-0,014$

$-0,056$

0,547

$-0,237$

0,221

$-0,005$

$-0,144$

Medicinske su sestre pomoćnice liječnika.

Napredak sestrinske struke ne ugrožava ostale članove tima.

Medicinska sestra ima jednaki autoritet kao i drugi članovi tima.

U budućnosti namjeravam raditi u području sestrinstva.

U budućnosti namjeravam nastaviti obrazovanje te napredovati na osobnom i profesionalnom planu.

\begin{tabular}{|c|c|c|c|c|}
\hline$-0,014$ & 0,393 & 0,248 & 0,155 & $-0,477$ \\
\hline$-0,162$ & 0,540 & 0,171 & 0,210 & 0,437 \\
\hline 0,344 & 0,042 & $-0,066$ & 0,596 & 0,512 \\
\hline 0,553 & 0,152 & $-0,138$ & $-0,362$ & 0,307 \\
\hline$-0,278$ & 0,368 & 0,173 & 0,173 & $-0,046$ \\
\hline 0,345 & $-0,369$ & 0,056 & $-0,151$ & 0,093 \\
\hline 0,429 & 0,195 & 0,305 & $-0,366$ & 0,340 \\
\hline 0,572 & $-0,242$ & 0,148 & 0,370 & $-0,066$ \\
\hline 0,602 & $-0,428$ & 0,180 & 0,193 & $-0,123$ \\
\hline
\end{tabular}

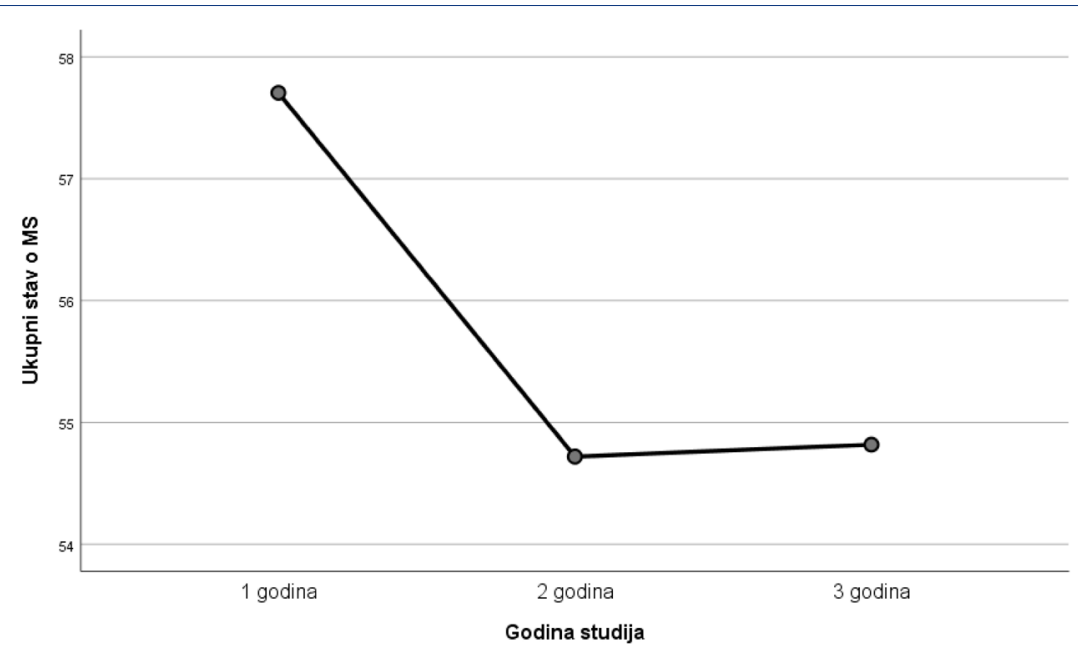

Slika 1. Grafički prikaz razlika u aritmetičkim sredinama u ukupnom rezultatu procjene stava za različite godine studija $(F=7,508 ; p<0,01)$ 
vatskoj adekvatno organizirano i da osigurava potrebna znanja i vještine, dok se studenti treće godine s tom tvrdnjom ne slažu. U usporedbi, ispitani studenti studija zdravstvene njege u Banjoj Luci, prema podacima istraživanja, svoj studijski program i kvalitetu izvođenja praktičnog dijela ocijenili su srednjom ocjenom ${ }^{29}$.

Da medicinske sestre raspolažu $\mathrm{s}$ dovoljno znanja i vještina za samostalan rad smatra gotovo polovina ispitanika svih godina studija sestrinstva, što potvrđuju rezultati istraživanja provedenog 2009. godine u Kanadi, prema kojima ispitanici smatraju da su medicinske sestre sposobne za samostalnu praksu ${ }^{27}$.

$S$ tvrdnjom da medicinska sestra može napredovati i steći znanja u području osobnog i profesionalnog interesa slaže se većina ispitanih studenata svih godina, što je u skladu s mogućnošću upisa specifičnih programa na diplomskim studijima te doktorskim radovima iz područja sestrinstva. Prema dobivenim podacima za tvrdnju cijene li drugi članovi tima medicinske sestre došli smo do zaključka da većina ispitanika smatra da nisu cijenjene od drugih članova tima, a također je visok postotak i onih koji nisu izrazili mišljenje. Istraživanje provedeno 2011. godine na trećoj godini preddiplomskog studija sestrinstva na Zdravstvenom veleučilištu u Zagrebu imalo je jednake rezultate za isto pitanje ${ }^{28}$.

Dosadašnja istraživanja koja su ispitivala mišljenja i stavove o medicinskim sestrama imala su jednake rezultate o tome da medicinske sestre nisu primjereno plaćene za posao koji obavljaju ${ }^{27,28,29}$. Isto mišljenje dijele ispitani studenti svih godina koji su sudjelovali u ovom istraživanju.

Dvije trećine ispitanih smatra da sestrinstvo nije cijenjena profesija, što se može usporediti s istraživanjem provedenim 2011. godine, gdje su ispitanici također izrazili jednako mišljenje ${ }^{28}$, a s tim su se složili i ispitani u Banjoj Luci $^{29}$, dok istraživanje u Kanadi donosi rezultate o sestrinstvu kao cijenjenoj profesiji ${ }^{27}$.

Gotovo svi ispitani studenti smatraju kako je cjeloživotno usavršavanje važno u sestrinskoj profesiji, a to podupiru podaci iz literature prema kojima sestrinstvo ima potrebu uključivanja medicinskih sestara u procese cjeloživotnog učenja radi očuvanja stečenih kompetencija i zadovoljavanja zahtjeva za provođenje novih metoda zdravstvene njege.

Istraživanje u sestrinstvu važno je za unaprjeđivanje struke, ali i funkcioniranje cjelokupnoga zdravstvenog sustava, a da je to zaista tako potvrđuju gotovo svi ispitani studenti sa svih godina. Ovakve rezultate pokazuju i ostala provedena istraživanja ${ }^{27,28}$. Sestrinska istraživanja važna su za razvoj novih teorija i spoznaja, bez kojih nema mogućnosti daljnjeg razvoja sestrinstva kao samostalne profesije.

Čak 206 od ukupno 281 ispitanika smatra da prikaz medicinskih sestara u medijima nije adekvatan, a također se velik dio ispitanika $(N=249)$ ne slaže $s$ tvrdnjom da se prilikom obraćanja članovima tima medicinsku sestru oslovljava smo imenom, a liječnike titulom i prezimenom. S rezultatima za obje tvrdnje podudaraju se rezultati istraživanja iz 2011. godine. $.^{28} 38,08 \%$ ( $\mathrm{N}=107$ ) ispitanih uglavnom se slaže da liječničke upute i smjernice imaju apsolutno autoritativnu snagu za profesiju samo ako su povezane s liječenjem bolesnika, a $40 \%$ ispitanih 2011. godine također se uglavnom slagalo $\mathrm{s}$ tom tvrdnjom ${ }^{28}$.

Ispitanici smatraju da su medicinske sestre autonomne u djelovanju u specifičnim kompetencijama vlastite profesije te se većina ne slaže s tvrdnjom da su medicinske sestre pomoćnice liječnika. Jednake rezultate također prikazuje i istraživanje provedeno na Zdravstvenom veleučilištu 2011. godine u kojem su sudjelovali studenti treće godine ${ }^{28}$.

S tvrdnjom da medicinska sestra ima jednak autoritet kao i drugi članovi tima ispitanici se ne slažu, a također velik broj ispitanih smatra da napredak sestrinske struke ne ugrožava ostale članove tima. Isto mišljenje dijele ispitani 2011. godine ${ }^{28}$.

Rezultati ostalih istraživanja ${ }^{28,29}$ i ovog istraživanja daju zadovoljavajuće podatke da velik broj ispitanih u budućnosti namjerava raditi u području sestrinstva. Većina ispitanih planira nastaviti obrazovanje te napredovati u vlastitoj profesiji. Istog su mišljenja studenti zdravstvene njege u Banjoj Luci, koji pokazuju veliki interes za daljnje napredovanje na diplomskim studijima.

Teorijski je raspon rezultata ukupnog stava u primijenjenom upitniku od 17 do 85 , a studenti su postizali sljedeće aritmetičke sredine: 1 . godina studija $=57,7 ; 2$. godina studija $=54,7 ; 3$. godina studija $=54,8$, a standardna devijacija kretala se od 5,44 do 6,29. Dakle, prosječna vrijednost rezultata bila je kod svih godina studija nešto iznad teorijskog prosjeka ljestvice.

Uočljivo je da se ukupni stav o vlastitoj budućoj profesiji kod studenta sestrinstva statistički značajno mijenja ka lošijim vrijednostima nakon prve godine studija, što bi se moglo interpretirati postupnim nestankom nerealnog optimizma nakon postupnog upoznavanja s različitim dimenzijama buduće profesije. 
Faktorska struktura podataka prikupljenih primjenom ovoga upitnika za procjenu stava ukazuje na multidimenzionalnost promatranog stava (može se uočiti čak pet dimenzija različite veličine), što je svakako povezano i s pokazateljima pouzdanosti procijenjenih metodom interne konzistentnosti. Dobivena veličina Cronbachova alfa koeficijenta 0,648 govori o ne pretjerano visokoj homogenosti i međusobnoj povezanosti čestica koje su upotrijebljene u primijenjenom upitniku. Interna bi se konzistentnost mogla povećati izbacivanjem ili drugačijim određenjem pojedinih čestica, a to bi vjerojatno i faktorsku strukturu učinilo manje složenom. Dobiveni pokazatelji daju podršku mogućnosti primjene anketnog upitnika za procjenu stava o sestrinstvu, identitetu profesije, ulozi i položaju u zdravstvenom timu, kao i stavova o obrazovanju, odnosno mišljenja o promjenama i novim mogućnostima u obrazovanju medicinskih sestara i tehničara.

\section{Zaključak}

Rezultati dobiveni istraživanjem 281 ispitanika u skladu su s očekivanjima. Istraživanje je pokazalo da studenti svih godina sestrinstva razmišljaju podjednako kada je riječ o stavovima o sestrinstvu.

Većina studenata prve i druge godine smatra da je obrazovanje medicinskih sestara u Republici Hrvatskoj adekvatno organizirano i da osigurava potrebna znanja i vještine, njih $45,45 \%(N=40)$ s prve godine te $40,45 \%$ ( $\mathrm{N}=36$ ) ispitanika s druge godine, dok se studenti završne godine sestrinstva uglavnom ne slažu s tom tvrdnjom $(28,85 \%(N=30))$ ili nemaju mišljenje $(31,73 \%$ $(\mathrm{N}=33))$. Velik broj ispitanih $(50,53 \%(\mathrm{~N}=142))$ sa svih godina studija smatra da medicinske sestre raspolažu s dovoljno znanja i vještina za samostalan rad.

Obećavajući je podatak da se $71,89 \%(\mathrm{~N}=202)$ ukupnog broja ispitanih u potpunosti slaže $s$ tvrdnjom da medicinska sestra može napredovati i steći znanja u području osobnog i profesionalnog interesa. Prema dobivenim podacima za tvrdnju cijene li drugi članovi tima medicinske sestre došli smo do zaključka da studenti svih godina dijele isto mišljenje. Ukupno 40,93 \% $(\mathrm{N}=115)$ ispitanika smatra da drugi članovi tima ne cijene medicinske sestre, dok se većina ispitanih 42,70\% $(N=120)$ niti slaže niti ne slaže s tom tvrdnjom, a osta- tak, odnosno manji dio $(16,37 \%(\mathrm{~N}=46))$ smatra da ih drugi članovi tima cijene.

Tvrdnju da su medicinske sestre primjereno plaćene za svoj posao negira $81,85 \%(\mathrm{~N}=230)$ studenata te gotovo dvije trećine $61,57 \%(\mathrm{~N}=173)$ studenata svih godina zajedno imaju isto mišljenje kako sestrinstvo nije cijenjena profesija u Republici Hrvatskoj. Gotovo se svi ispitani studenti, njih 98,58\% ( $N=277$ ) od ukupno 281, slažu da je cjeloživotno usavršavanje važno u sestrinskoj profesiji.

Većina ispitanih studenata, budućih profesionalaca, njih $57,65 \%$ ( $N=162$ ) sa svih godina studija smatra da su medicinske sestre autonomne u djelovanju u specifičnim kompetencijama vlastite profesije. 77,58\% $(\mathrm{N}=218)$ ispitanika uopće se ne slaže s tvrdnjom da su medicinske sestre pomoćnice liječnika. Ispitanici svih godina dijele jednako mišljenje o tvrdnji da medicinska sestra ima jednaki autoritet kao i drugi članovi tima.

Zadovoljavajući je podatak da velik broj ispitanih, čak $94,31 \%(\mathrm{~N}=265)$, u budućnosti namjerava raditi u području sestrinstva. Velik broj ispitanih planira nastaviti obrazovanje te napredovati u vlastitoj profesiji, njih $92,53 \%$ ( $N=260$ ) od 281 ispitanih, što ostavlja dovoljno prostora za sve svjetliju budućnost i razvoj sestrinstva u Republici Hrvatskoj.

Rezultati analiza govore da je primijenjeni upitnik odgovarajućih metrijskih osobina za upotrebu i da pouzdano može ukazati na važne dimenzije stava o sestrinstvu.

\section{Referencije}

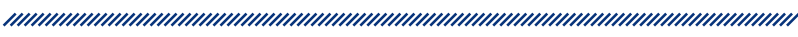

1. Directive 2005/36/EC of the European Parliament and of the Council. Dostupno na: http://eur-lex.europa.eu (pristupljeno 20.5.2018.).

2. Directive $2013 / 55 / E U$ of the European Parliament and of the Council. Dostupno na: http://eur-lex.europa.eu (pristupljeno 20.5.2018.).

3. Milisen K, De Busser T, Kayaert A, Abraham I, Dierckx de Casterle $B$. The evolving professional nursing self-image of students in baccalaureate programs: a cross-sectional survey. Int J Nurs Stud 2010;47:688-98.

4. Dal U, Arifoglu BC, Razi GS. What factors influence students in their choice of nursing in North Cyprus? Procedia Social and Behavioral Sciences 2009;1:1924-30.

5. Buerhaus P, Donelan K, Norman L, Dittus R. Nursing students' perceptions of a career in nursing and impact of a national campaign designed to attract people into the nursing profession. J Prof Nurs 2005;21(2):75-83. 
6. Bridges JM. Literature review on the images of the nurse and nursing in the media. J Adv Nurs 1990;15:850-4.

7. Jinks AM, Bradley E. Angel, handmaiden, battleaxe or whore? A study which examines changes in newly recruited student nurses' attitudes to gender and nursing stereotypes. Nurs Educ Today 2004;24:121-7.

8. Kelly J, Fealy GM, Watson R. The image of you: constructing nursing identities in YouTube. J Adv Nurs 2012;68(8):1804-13.

9. Cabaniss R. Educating nurses to impact change in nursing's image. Teach Learn Nurs 2011;6:112-8.

10. Cohen S. Reflections on the image of nursing. HCPro. Dostupno na: www.hcpro.com (pristupljeno 20.6.2018.)

11. Donelan K, Buerhaus P, DesRoches C, Dittus R, Dutwin D. Public perceptions of nursing careers: the influence of the media and nursing shortages. Nurs Econ 2008;26(3):143-65.

12. ten Hoeve $Y$, Jansen G. Roodbol P. The nursing profession: public image, self-concept and profession identity. A discussion paper. J Adv Nurs 2014;70:295-309.

13. ten Hoeve Y, Jansen WS, Jansen GJ, Roodbol PF. Nursing students' changing orientation and attitudes towards nursing during education: A two year longitudinal study. Nurs Educ Today 2017; 48:19-24.

14. Dante A, Valoppi G, Saiani L, Palese A. Factors associated with nursing students' academic success of failure: A retrospective Italian multicenter study. Nurs Educ Today 2011;31(1): 59-64.

15. Johnson M, Cowin LS, Wilson I, Young H. Professional identity and nursing: contemporary theoretical developments and future research challenges. Int Nurs Rev 2012;59:562-9.

16. Gray M, Smith LN. The professional socialization of diploma of higher education in nursing students (Project 2000): a longitudinal qualitative study. J Adv Nurs 1999;29(3): 639-647.

17. Weis. D, Schank, MJ. Professional values: Key to professional development. J Prof Nurs 2002;5:271-5.

18. Ousey K. Socialization of student nurses - the role of the mentor. Learning in Health and Social Care 2009:8(3):17584.
19. Day RA, Field PA, Campbell IE, Reutter L. Student's evolving beliefs about nursing: From entry to graduation in a four-year baccalaureate programme. Nurs Educ Today 2005;25: 636-43.

20. Ghadirian F, Salsali M, Cheraghi MA. Nursing professionalism: An evolutionary concept analysis. Iranian Journal of Nursing and Midwifery Research 2014:19(1):1-10.

21. Watson R, Deary IJ, Lea A. A longitudinal study into the perceptions of caring and nursing among student nurses. J Adv Nurs 1999;29:1228-37.

22. Karaoz S. Change in nursing student' perceptions of nursing during their education: the role of the Introduction to Nursing course in this change. Nurs Educ Today 2004:24;128-35.

23. Granum V. Nursing students perceptions of nursing as a subject and a function. J Nurs Educ 2004;43:297-304.

24. Sand-Jecklin K, Schaffer A. Nursing students' perceptions of their chosen profession. Nurs Educ Perspect 2006;27(3):130-5.

25. Safadi RR, Saleh MYN, Nassar OS, Amre HM, Froelicher ES. Nursing students' perceptions of nursing: a descriptive study of four cohorts. Int Nurs Rev 2011;58(4):420-7.

26. Grainger P, Bolan C. Perceptions of nursing as a career choice of students in the Baccalaureate nursing program. Nurs Educ Today 2006;26:38-44.

27. Bolan C, Grainger P. Students in the BN program-Do their perceptions change? Nurs Educ Today 2009;29:775-9.

28. Čukljek S, Karačić J, Ilić B. Stavovi studenata 3. godine studija sestrinstva o sestrinstvu u Hrvatskoj danas. Zbornik radova konferencije medicinskih sestara "Hrvatsko sestrinstvo ususret Europskoj uniji“, Opatija 2011. Dostupno na: https://www.zvu.hr/arhiva/opatija/arhiva/2011/ zbornik/zbornik.pdf

29. Jović D, Knežević D, Skrobić M, Matavulj A, Vučković J. Stavovi i mišljenja studenata zdravstvene njege Medicinskog fakulteta u Banjoj Luci o studijskom programu i sestrinstvu kao profesiji. Scripta Medica 2015; 46(1):48-53. 


\section{ATTITUDES OF NURSING STUDENTS AT THE UNIVERSITY OF APPLIED HEALTH SCIENCES ON NURSING IN CROATIA}

1 Mateo Kosier

2 Snježana Čukljek

2 Damir Lučanin

1 Clinical Hospital Center Sisters of Mercy

2 University of Applied Health Sciences

\section{Abstract

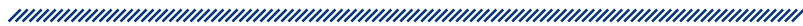

Nursing is nowadays a recognized profession that no one disputes. Modern nursing favors education as a priority in the professional life of nurses. Post-secondary and higher education of nurses is a standard in modern states. The success of a nurse depends not only on her humaneness and the ability to master modern technology, but also on the continuing education of nurses. The aim of this study was to investigate the attitudes and opinions nursing students of all three years of the undergraduate study have on nursing, identity of the profession, role and position in the health care team and education, and changes and possibilities in the education of nurses in the Republic of Croatia. A total of 281 respondents from all three years of the undergraduate nursing study participated in the study. The highest number of participants, $87.19 \%$ $(\mathrm{N}=245)$, are 19 to 22 years old. As expected there is a higher number of female respondents, $91.46 \%(N=257)$, while only $8.54 \%(\mathrm{~N}=24)$ of the male respondents participated in the research. The obtained results show a great interest in strengthening nursing as a profession and the advancement of nursing towards a brighter and better future in the Republic of Croatia.
Keywords: nursing, education, research, professionalism, attitudes 